H A R VAR D

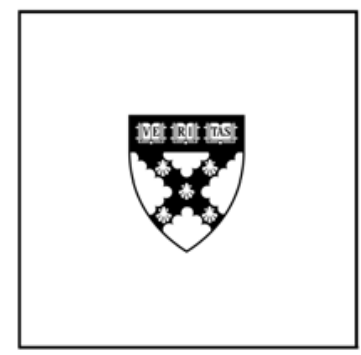

\title{
The Triumph of the Humble Chief Risk Officer
}

\author{
Anette Mikes
}

\section{Working Paper}

14-114

May 23, 2014

Copyright (C) 2014 by Anette Mikes

Working papers are in draft form. This working paper is distributed for purposes of comment and discussion only. It may not be reproduced without permission of the copyright holder. Copies of working papers are available from the author. 


\title{
The Triumph of the Humble Chief Risk Officer
}

\author{
Anette Mikes \\ Harvard Business School
}

\begin{abstract}
This paper tracks the evolution of the role of two chief risk officers (CROs), and the tools and processes they have implemented in their respective organizations. While the companies are from very different industries (one is a power company, the other is a toy manufacturer), they both embraced the concepts and tools of Enterprise Risk Management. Over a number of years, at both firms, risk management transformed from a collection of "off-theshelf", acquired tools and practices into a seemingly inevitable and tailored control process. The paper investigates the role of the CRO in making these transformations happen. The two cases highlight that the role of the CRO may be less about the packaging and marketing of risk management ideas to business managers, but instead, the facilitation of the creation and internalization of a specific type of "risk talk" as a legitimate, cross-functional language of business. Thereby the risk-management function may be most successful when it resists conventional and conflicting demands to be either close to, or independent from, business managers. Instead, by acting as a facilitator of risk talk the CRO can enable the real work of risk management to take place not in his own function, but in the business. In both cases, facilitation involved a significant degree of humility on the part of the CRO, manifest in limited formal authority and meagre resources. Their skill was to build an informal network of relationships with executives and business managers, which allowed them to resist being stereotyped as either compliance champions or a business partners. Instead they created and shaped the perception of their role which was of their own making: a careful balancing act between keeping one's distance and staying involved.
\end{abstract}


In the wake of the 2007-2009 financial crisis, continuing corporate debacles, and ongoing corporategovernance calls for the appointment of chief risk officers (CROs) and risk-management committees, it is particularly important to understand what role risk officers (may) play in organizational life. The compliance imperative requires banks to implement a firm-wide risk management framework complete with analytical models for the measurement and control of quantifiable risks. In addition, corporate governance guidelines advocate the "business partner" role of risk management. In this context, the question becomes: how do senior risk officers strike a balance between the twin roles of "compliance champion" and "business partner"?

The practitioner literature on risk management promotes the view that the chief risk officer should focus on developing fruitful interactions between risk managers and the organization's managerial and executive layers (Economist Intelligence Unit Limited, 2010); for example, by positioning themselves "as a strategic business advisor" (KPMG, 2011: 27). The rising visibility of enterprise risk management and risk managers in organizations reflects an apparent and ongoing reconfiguration of uncertainty into an area of management (Power, 2007), which places demands on the "risk manager" to be a proactive assessor and communicator of uncertainty, capable of operating as a potential partner to business decision makers rather than as a reactive control agent.

Seemingly, risk managers are riding a favorable tide with regulators, standard-setters, and some emerging professional associations advocating their value. An increasing proportion of companies have appointed CROs over the last decade, and surveys demonstrate that the proliferation of senior risk officers is ubiquitous ${ }^{1}$. While only a minority of respondents tend to treat COSO's Enterprise Risk Management (ERM) framework (COSO, 2004) as their blueprint, and many do not follow any particular standard or framework ${ }^{2}$, surveys generally agree that the numbers of companies embracing ERM (i.e. reporting to have "an ERM framework and/or an ERM policy") have reached the "critical mass of $60 \%$ (RIMS, 2013; Deloitte, 2013). Putting money to the proverbial mouth, companies have spent increasing resources on risk management and many are planning to continue doing so. ${ }^{3}$ Yet the jury is still out on ERM's actual value added - according to a survey of risk managers, carried out by RIMS in 2013, their satisfaction with their progress was widely varied, and according to another survey of C-suite executives, less than half believe their organization have an effective risk-management program (KPMG, 2013).

At best, evidence tells us that organizations vary widely in their design, implementation, and use of risk management practices and tools. At worst, risk management (or the appointment of CROs) is a faddish phenomenon, taking up increasing amounts of resources yet proving incapable of closing the "expectations gap" (Power, 2007) that is now all-too evident between aspirations for better risk management and the actual achievements and capabilities of risk-management functions.

\footnotetext{
${ }^{1}$ A recent survey (Accenture, 2013) of a sample of 446 large, diverse organizations (which included financial services (46\%) and other organizations from the utilities, healthcare, life sciences and government sectors) found that the presence of the CRO, or equivalent senior risk officer, was "near-universal" with 96\% of respondents having one in 2013 (up from 78\% in 2011). However, surveys that have less focus on regulated industries suggest that the acceptance of CROs (and formal risk-management functions) could be much less widespread - $31 \%$ in global firms (AICPA, 2010) and even lower in non-regulated U.S. organizations.

2 This 2013 survey of 1095 risk managers (RIMS, 2013) suggests that 22\% of companies adopted the COSO framework, 23\% embraced the ISO 31,000 standard and $26 \%$ does not follow any particular framework in defining their "enterprise risk management" practices.

${ }^{3}$ A global survey of 1,092 respondents from diverse industries, carried out in late 2012 ( KPMG, 2013) found that the level of investment in risk management has grown as a percentage of total revenues in the past three years, with $66 \%$ of respondents expecting the proportion invested in risk management to rise in the next three years.
} 
This paper focuses on two companies where the risk management staff had successfully defined and brought about their version of risk management. Having traced the evolution of these two riskmanagement functions, their apparatus (tools and processes), and their relationship with the rest of the organization, I was struck, first, by the apparent success of these CROs at making risk management a seemingly inevitable, inconspicuous part of organizational life. Over the years, they developed new tools that seamlessly linked up with the work of business managers, creating the impression that the real work of risk management took place in the business lines, and was carried out by employees. Yet the risk managers (or rather, the risk-function managers) retained a certain amount of attachment to these practices that enabled them to demarcate risk management as their expertise and raison d'etre.

Secondly, I was also intrigued by the paradoxical attitudes displayed by these CROs towards their own work: they appeared to be tremendously confident and surprisingly humble. The CROs were surrounded by corporate governance advocates, regulators, consultants and certified risk professionals with a vested interest in telling them what risk managers should do and be. But they had the confidence to steer away from the emerging conventional wisdom, the risk-management standards and guidelines, and the "charlatans" who advocated them. They took on the challenge to develop the idea of risk management and its apparatus themselves. Yet at the same time, they displayed a lot of humility, acknowledging failures, struggles and imperfections. They regarded their work unfinished.

Thirdly, these CROs sensed that the excessive use of certain kinds of risk-management vocabulary, technology, and their uncritical adaption could harm, rather than further their cause. Irritated by the proliferation of abstract vocabulary emanating from risk-management standards, these CROs tried to learn and speak the language of the business. By co-creating risk tools and a sparse risk vocabulary with those who were to use them, these CROs brought about inconspicuous risk talk - managers were not even conscious of speaking a new language, that of risk management.

Finally, these CROs operated extremely frugally - with one or two full-time staff, they played the role of the facilitator of risk talk, and kept their resource requirements to a bare minimum. They planned no further "investment in risk management", and did not ask for increases in their formal authority or decision rights. Towards the end of the research horizon, at both companies the role of the CRO was structurally demoted (one or two steps further removed from the CEO in the reporting hierarchy), yet their organizational reach and influence remained unchanged.

Thus, the two case studies document what might be called the triumph of the humble CRO over the advocates of ever-more visible, better-resourced and highly independent risk managers. It is the triumph of ordinary risk talk and an unobtrusive risk apparatus over ever-more sophisticated risk models and offthe-shelf IT programs that promise a comprehensive and elaborate display of risks. The following sections aim to describe the movements of this evolution, as evidenced by the case studies. I start with a brief description of the case sites and the research process. Second, I outline the evolution of the risk apparatus and describe the work of risk management ("riskwork") at the two companies. Third, I describe their efforts at facilitating inconspicuous risk talk and unobtrusive risk tools. Next, I illustrate the mix of confidence and humility that characterized the attitude of these CROs towards their own creations. Here I shall also describe how these CROs kept their span of control (Simons, 2005) narrow, 
and even came to accept less formal authority, while (somewhat counterintuitively) they succeeded at widening their span of support ${ }^{4}$.

\section{The case sites and research process}

Electroworks, a major Canadian power utility, operated in an industry in which lack of reliability could lead not only to financial and asset damage but also to human injury and death. The provincial regulatory agency had capped the price that Electroworks could charge, while also requiring it to lead conservation initiatives that would reduce future revenues and earnings. Electroworks had to manage a complex web of conflicting interests - the agendas of government ministers, regulators, consumers, environmental groups, aboriginal ("first nation") landowners, and the capital-market debt-holders that had subscribed to the company's $\mathrm{C} \$ 1$ billion bond issue. I started field work at Electroworks in spring 2008. Through 25 interviews (see Appendix 1 for a list of interviews), I aimed to reconstruct the history of ERM from its original consultant-led introduction through its transformation to its current inevitable, yet still unfinished and evolving state.

Magic Toys was a large, family-owned toymaker, operating within a highly competitive, fast-paced industry, which essentially produces and markets "fashion for kids". The majority of the company's annual sales came from new product launches, which elevated the importance of product development and innovation. The firm's primary customers were the global retailers who distributed children's toys. Serving these retail chains with accurate and timely deliveries, and ensuring their fast shelf-turnover were of paramount importance in Magic Toys' business model, which aspired to possess "world-class" marketing and distribution capabilities. In this context, risk management's role was to assist the smooth delivery of new product lines (each carried out as a separate project) and to "prepare the company for uncertainty". I started field work at Magic Toys in 2010, and through 44 interviews (see Appendix 2 for a list of interviews) with risk-function managers and business executives, I tried to sketch the evolution of risk practices from "form-filling" to an established, actionable and consequential part of the annual planning exercise.

\section{The evolution of the risk-management apparatus}

\section{Origins}

Early 1999, in preparation for listing on the Toronto Stock Exchange, the board of directors at Electroworks decided that the company should implement enterprise risk management (ERM), in compliance with listing requirements ${ }^{5}$. They hired a succession of four consulting firms who (in the words of the later chief risk officer) "all came through doing ERM-type stuff. They would come in. They would do risk interviews. They would do risk maps. They would charge a quarter of a million dollars, and deliver a nice report. But nothing happened; there was no knowledge transfer." After this perceived false start, the CEO and

\footnotetext{
${ }^{4}$ In Simons' Levers of Oragnizational Design framework, span of control indicates the financial and non-financial resources that managers and employees can draw on in order to accomplish their tasks. Span of support indicates the amount of support they can expect to receive from others in the organization when they reach out for help.

${ }^{5}$ Although Electroworks eventually abandoned its listing plans, ERM remained.
} 
CFO asked the head of internal audit, Robert Lewis ${ }^{6}$ "to take on ERM" with very little directive, out of a sense of need conveyed by the board and the listing requirements. Originally hired from the banking industry to be the head of internal audit, Lewis had little expertise in any of the day-to-day challenges faced by Electroworks' line-workers, engineers, lawyers and customer service managers. Trained as an accountant and experienced as an internal auditor, Lewis saw risk management both as a challenge and a development opportunity for his control function. He realized that he could make this function his own, and have a wide span of control over defining what risk management was to be:

"They [the CEO and the CFO] decided they wanted ERM. They didn't know what it looked like. They were just told [by the board and the stock exchange] that it was a good thing to have. Initially I said, "No, I don't think I should take it on. I think there's a conflict of interest, because of my audit role, but let me think about it, I'll sleep on it and get back to you tomorrow." So, I went home and I thought about it, and I guess my feeling was that before the consultants nothing had happened in the risk domain. Now after the consultants had left, nothing was happening. And while it might be a little bit of a conflict, I felt, well, it might be fun. I'll give it a shot, but I'll run it as a completely separate product line."

Lewis established a "Chinese wall" to separate his internal audit role from his risk management one. Records of the risk workshops were kept confidential and separate from internal audit assessments and no one, besides himself, was involved in both activities. He had the habit of signaling which hat he was wearing by actually appearing in meetings with a baseball cap carrying either the Internal Audit or the ERM label.

In contrast to Lewis, Carl Hirschman, ${ }^{7}$ Magic Toys' CRO, spent his entire career in the company, as a financial controller. The notion of risk management came to him as an out-of-the-blue request from his boss, the CFO in 2007. At the time, Magic Toys was recovering from a serious crisis that saw high staff turnover and the appointment of the company's first ever "outside" CEO (a former McKinsey consultant). As part of the recovery, the board requested that the company should adopt "riskmanagement best practices". Similarly to Lewis, Hirschamn initially refused to take on the role, but then ended up defining it for himself:

[Initially,] I said, "No, because that's a compliance job, and I don't want to spend the rest of my career doing compliance. Forget it. I don't have the patience for it." The next day, the CFO came to my office and said, "What would it take?" So I went to his office on the following Monday -I spent most of the previous weekend reading about risk management - and I said, "I want risk management to be proactive. I want to run a strategic process. I want to focus on value creation more than value protection. I didn't want to do compliance validation all the time." And the CFO said, "Yeah, go ahead."

Hirschamn's first realization was that many of the risk areas defined in the ERM frameworks, in case of Magic Toys, were already monitored and managed by specific functions. In an internal memo, he declared: Operational risk is handled by planning and production. Employee health and safety is OHSAS 18001 certified. Hazards are managed through explicit insurance programs... IT security risk is a defined functional area.

\footnotetext{
${ }^{6}$ Pseudonym

${ }^{7}$ Pseudonym
} 
[The finance department] covers currencies, hedging and credit risks, And [the legal function] is actively pursuing trademark violations... Only strategic risks aren't handled explicitly or systematically...

Rather than positioning the would-be "risk-management function" as an umbrella function for all of these risk areas, Hirschman decided to find a niche for it - "strategic risk"- and called the new function Strategic Risk Management. Hiring only two employees, he searched for meaningful opportunities and tools that would contribute to the management of the business.

\section{Timelines}

Over time, Lewis introduced a three-phase enterprise risk management program, consisting of risk workshops, bi-annual risk updates and, linked to the annual planning process, risk-based resource allocation. The following timeline summarizes the evolution of these phases.

\begin{tabular}{|c|c|c|c|}
\hline & $1999-2000$ & $2000-2004$ & 2004-2012 \\
\hline $\begin{array}{l}\text { Facilitator } \\
\text { s of risk } \\
\text { work }\end{array}$ & Consultants & $\begin{array}{l}\text { CRO; risk team of } 2 \text { and } \\
\text { Investment Management } \\
\text { department }\end{array}$ & $\mathrm{CRO}$; risk team of 2 \\
\hline $\begin{array}{l}\text { Fora for } \\
\text { risk talk }\end{array}$ & Interviews & $\begin{array}{l}\text { Workshops; one-to-one } \\
\text { interviews; annual planning } \\
\text { and resource allocation } \\
\text { debates }\end{array}$ & $\begin{array}{l}\text { Workshops; one-to-one interviews; } \\
\text { annual planning and resource allocation } \\
\text { debates; "black swan workshops" }\end{array}$ \\
\hline Risk tools & $\begin{array}{l}\text { Consultants' } \\
\text { risk- } \\
\text { assessment } \\
\text { templates }\end{array}$ & $\begin{array}{l}\text { In-house risk-assessment } \\
\text { templates (for workshops and } \\
\text { investment proposal } \\
\text { evaluation); } \\
\text { Headline news updates for } \\
\text { interview discussion; } \\
\text { Bi-annual Corporate Risk } \\
\text { Profile reports }\end{array}$ & $\begin{array}{l}\text { As before, plus: } \\
\text { In-house template for "black swan" } \\
\text { evaluation }\end{array}$ \\
\hline $\begin{array}{l}\text { Frequency } \\
\text { of formal } \\
\text { risk } \\
\text { meetings }\end{array}$ & $\begin{array}{l}4 \text { projects } \\
\text { carried out } \\
\text { by different } \\
\text { consulting } \\
\text { firms }\end{array}$ & $\begin{array}{l}40-50 \text { risk workshops; } \\
\text { Bi-annual risk updates } \\
\text { (interviews); } \\
\text { Annual planning (with the } \\
\text { involvement of investment } \\
\text { management department) }\end{array}$ & $\begin{array}{l}\text { 5-12 risk workshops; } \\
\text { Bi-annual risk updates (interviews); } \\
\text { Annual planning (no investment } \\
\text { management department); } \\
\text { Bi-annual CRO presentation to the full } \\
\text { board; } \\
\text { Ad hoc black swan workshops (from } 2008 \\
\text { on) }\end{array}$ \\
\hline
\end{tabular}

Initially, "riskwork" at Electroworks was manifest in the proliferation of risk-management workshops in which participants evaluated "risk impact", "probability of risk occurrence" and "control strength" (in order to get a sense of "residual risk"). The workshops achieved a consensus assessment on each of these dimensions by repeated and anonymous voting, with intermittent discussions, facilitated by a risk officer ("Workshop Facilitator"). Once the management team had assessed risks and controls, the risk officers prepared a risk map-a two-dimensional rank-ordered chart of "residual risks." 
Twice a year, in January and July, Lewis and his team prepared a Corporate Risk Profile report for the executive team (bi-annual risk updates). He also presented the report in person to the Audit Committee, and from 2004 on, to the entire board of directors. The Corporate Risk Profile summarized the principal risks facing the organization.

To prepare for the final phase of the ERM process (risk-based resource allocation), the investment planning department and the risk management team jointly developed templates for allocating resources. Engineers (challenged by the investment planning department) had to evaluate their proposals in terms of cost and the severity of the risk that their program aimed to mitigate. They calculated a "bang for the buck" index to show the risk reduction per dollar spent, and ranked the investment programs accordingly. By 2004, the engineering teams and top management were both sufficiently "fluent" in risk and cost assessments that they were able to do without the investment-management department. The investment management department was dissolved - yet the risk management team, and the practice of risk-based resource allocation, remained.

In 2008, responding the global financial crisis and a world-wide concern with systemic risks and "black swan" events", Lewis and his team initiated so-called "black swan workshops," a separate process to focus executives' and board members' attention on low-probability high-impact events that did not normally come up during risk workshops and the bi-annual risk updates. These discussions used a new template, asking directors to consider the "velocity of the underlying trend" and the company's perceived "resilience" to such events. Lewis described these workshops as "more a thought experiment than a risk workshop." The "black swan workshops" were held on demand (but at least annually). Insights from the "black swan workshops" were fed back into the company's disaster recovery plans.

The following timeline summarizes the evolution of the risk-management processes and apparatus at Magic Toys.

\begin{tabular}{|l|l|l|l|}
\hline & 2006-2008 & 2009 & 2010-2012 \\
\hline $\begin{array}{l}\text { Facilitator } \\
\text { s of risk } \\
\text { work }\end{array}$ & $\begin{array}{l}\text { CRO plus risk team of } \\
1\end{array}$ & CRO plus risk team of 2 & CRO plus risk team of 2 \\
\hline $\begin{array}{l}\text { Fora for } \\
\text { risk talk }\end{array}$ & $\begin{array}{l}\text { Risk and opportunity } \\
\text { identification }\end{array}$ & $\begin{array}{l}\text { Risk and opportunity } \\
\text { identification; } \\
\text { Ad hoc scenario exercise } \\
\text { (failed) }\end{array}$ & $\begin{array}{l}\text { Risk and opportunity identification; } \\
\text { Regular scenario planning }\end{array}$ \\
\hline Risk tools & $\begin{array}{l}\text { Spreadsheet tool for } \\
\text { risk and opportunity } \\
\text { identification; } \\
\text { Bi-annual ERM Report }\end{array}$ & $\begin{array}{l}\text { Spreadsheet tool for risk } \\
\text { and opportunity } \\
\text { identification; } \\
\text { Bi-annual ERM Report; } \\
\text { Scenarios (external Davos } \\
\text { scenarios) }\end{array}$ & $\begin{array}{l}\text { Spreadsheet tool for risk and } \\
\text { opportunity identification; } \\
\text { Bi-annual ERM Report; } \\
\text { Scenarios (internally generated) }\end{array}$ \\
\hline
\end{tabular}

\footnotetext{
8 Popularized by author Nassim Nicholas Taleb, a black swan is an event, positive or negative, that is deemed improbable yet causes massive
} consequences. See Taleb, N. The Black Swan - The Impact of the Highly Improbable. Allen Lane, 2007. 
Noting that Magic Beans was a project-focussed organization (with each project leading to a new product release or a process improvement), Hirschman defined risk at the level of projects, as "a change, which negatively impacts our ability to achieve our targets and goals with the strategies and initiatives defined $^{9 \prime}$ and gave managers a list of examples ("loss of consumer affinity; loss of major customer; changes in the competitive landscape; loss of integrity; major supply chain disruptions").

Hirschman's first deliverable to the Magic Toys board was a 15-page report on the strategic risks (including a two-page "bullet list and a single chart"), as assessed by the business lines. The report was based on a spreadsheet that Hirschman developed for the interrogation and collection of strategic risk information.

The board reports got updated bi-annually. In between, Hirschman and his team introduced scenario planning in an effort to help managers "prepare for uncertainty", but also, for the periodic reassessments of the 110 risks they collectively logged in the risk spreadsheet. After an initial fiasco, the scenario exercise was redesigned for higher relevance, spread - and by 2012, became an integral part of Magic Toys' planning process.

\section{Inconspicuous risk talk and unobtrusive risk tools}

Lewis acknowledged that the risk assessment process at Electroworks was subjective, not "scientific." Yet the risk workshops were an instant and enduring success, as explained by one risk officer (the Workshop Facilitator"):

Our original ambitious plan was to do twelve risk assessments a year. The senior executive team embraced the approach so enthusiastically that one year we did 60 different risk assessment workshops. My role was to help executives tell their bosses about the risks they faced and how they were mitigating those risks. We helped them make judgments about the adequacy of the mitigating actions proposed and taken.

In order to make the risk assessment-discussions relevant, the risk team realized that their tools (riskassessment templates) had to be perceived as relevant too. They asked senior managers, who had accountability for the particular risk areas (financial, regulatory etc.), to review and approve the impact scales annually. Thus the CFO defined and reviewed the financial scale, the chief regulatory officer reviewed the regulatory scale, and so on. In the end, the impact scale represented every business functions' concern, in parallel to others' - resembling to a multi-language manual that everyone concerned could read (see Appendix 3). Lewis described how business managers used the template:

Let's assume we had an environmental spill of 10,000 liters of oil. We ask people to vote on a scale of one to five as to the consequences if our controls didn't work. A financial person could use the financial scale by stating, "the last time we had an oil spill, it cost \$10 million to clean up; I call it a 4." The environmental specialist could assess its impact by saying, "this could cause a significant local off-site impact, I am going to vote a 3." The head of public relations says "if it gets reported in the local press, the Toronto Star, I would

${ }^{9}$ Internal document, "Version 2.0 /15 March 2012" 
call it a 3. If the spill gets into the waterways, it would get covered by the national press, and then I'm going to vote a 4." Each person in the room identifies a different impact, based on his or her area of expertise. It brings a lot of clarity.

Having co-created the language of risk assessments with the business lines, Lewis also co-opted business managers in setting the agenda for the risk workshops. Prior to each risk workshop, Lewis' risk team informally polled participants and drew up a generic list of 60-70 potential risks or threats to the business or the project being discussed. They e-mailed the list to the participating management team asking them to choose the ten most critical risks facing their business or project. Based on these choices the risk team narrowed the list to 8-10 risks. A risk officer then started the half-day risk assessment workshop with the presentation of the shortlisted risks, and asked participants to confirm whether these were in fact the most important risks or whether any others should be discussed in detail instead.

In order to prepare the bi-annual risk updates, Lewis did a series of interviews with the top 30 to 40 executives and consulted other sources, such as annual business plans and risk workshops. But generally, these discussions were driven by managerial concerns, which Lewis merely directed into reporting templates:

I take the one-page strategic objectives, the news update and the summary of the previous risk assessments to all interviews, so the context is clearly set. Then I pull out the empty risk profile template and ask what had changed, what is new. The risk assessments could change because of the mitigation steps taken, or because of external changes in the environment. Some people grab the template and start filling it out on the spot. Others will literally shut their eyes, put their feet up on the desk and tell me what is worrying them.

All three phases of ERM at Electroworks channeled risk information vertically and horizontally throughout the company, enabling executives and employees to develop a shared understanding of what risks the company faced and what had to be done about them. Indeed, by 2008, Lewis noted that the workshops facilitated the rise of participants' understanding of their own risks in the context of those faced by others:

Magic occurs in risk workshops. People enjoy them. Some say, "I have always worried about this topic, and now I am less worried because I see that someone else is dealing with it, or I have learned it is a low-probability event." Other people said, "I could put forward my point and get people to agree that it is something we should be spending more time on, because it is a high risk."

At the same time, participants were using a new vocabulary - a specific, yet to them unobtrusive risk talk, which allowed them to voice their concerns more precisely. Lewis permitted himself a broad smile as he recalled what he considered as his team's ultimate achievement:

The management team got so familiar with coming to workshops and understanding what the scales were and how to vote, that it just became part of their language to the extent that they started to do some of the stuff on their own and now the big thrill for me is when I go to a management meeting, they're using all of the ERM terminology with residual risk and mitigation... It's just great to see [that] and they understand each other and they're really speaking a common language. 
In his policy document (written for the board) Hirschman insisted that Magic Toys" "Strategic Risk Management(SRM) processes are defined to largely comply with the ISO 31.000 standard". Hirschman very deliberately referenced the International Standards Organization, as an external source of credibility that managers recognized and associated with the same standards that upheld the values of quality and excellence in their manufacturing operations. Yet Hirschman departed from ISO 31.000 as he was defining SRM at the project-level (not at the level of the enterprise).

He also recognized that the extensive ERM vocabulary emanating from ISO 31.000 was counterproductive: "Initially we came [to managers] with a lot of risk-management jargon and got thrown out of the door. Nobody understood what we said. I learnt quickly that it's important for us risk managers - my teamthat we speak the language of the business. We want to make it as simple and intuitive as possible."

Hirschman recruited a former project manager (Lynne Matte ${ }^{10}$ ) and set out to explain the "raison d'etre" of risk management to project managers in their language. In series of meetings with project managers, having jokingly agreed that "a project is a dream with a deadline", Hirschman and Matte declared: "Our starting point is that our task is to make you shine. Whether you fail or succeed with the project is your responsibility. But we have some tools and an approach and a process that can help you succeed, even if the world turns out to be different from what you have hoped for."

Hirschman and his team "chased" project managers for risk updates twice a year, using the risk register (and Excel spreadsheet) as the channel of communication. But they also had the convening power to get together senior managers to discuss discretionary strategic issues and their implications for the company:

Every now and then, that is, every time we change strategic direction, I gather people, specialist people, mostly senior, mostly directors, senior directors, and a couple of VPs to discuss: with this strategic initiative, what do you see from your perspective? Tell me all about the risks that say: "OK, now we can't go to Asia, or we have to go to Asia in a different way than we thought we would." Then I update my risk database based on that.

Hirschman's risk inquiries became not only ubiquitous, but expected as well, and managers started to proactively share risk information with the risk team. Hirschman recalled, "When something happens, like in the case of the Icelandic ash cloud or the tsunami in Japan, at least fifteen people emailed me to say 'do you have this in your risk database?'"

In 2009, Hirschman and his team, looking for increasing "support" they could provide to the business, convened a senior managers' meeting to discuss the implications of a set of four strategic scenarios, based on the megatrends defined by the World Economic Forum in 2008 for the Davos meetings. Hirschman's report, summarizing the discussions, ended up "in the bottom of everybody's drawer, because nobody could relate to the scenarios that we have done."

Having learnt from the experience, Hirschman redesigned the scenario process to allow managers to generate scenarios based on their own worries, with the risk team providing mere suggestions for the

10 Pseudonym 
"dimensions of uncertainty" that managers can pick from and freely add to. Secondly, he initiated scenario discussions to explicitly "support" business managers with the preparation of their annual plans. In the scenario sessions managers listed issues they had to contend under each scenario, and then prioritized them (based on their likelihood and the speed of their emergence). The sessions never concluded without an hour-long discussion of "Act" issues - managers had to agree explicitly "who is doing what by when" about the fast-emerging, most likely issues.

Hirschman considered the introduction of the "fifth hour" (and the inclusion of the "Act-issues" in the annual business plans) as the turning point: "And that was it. That final discussion makes sure that the "Actissues" are actually acted upon. It was a hint given to us from two members of our [top management]. Then it just became part of the business planning process."

Scenario planning became part of Magic Toys' business-planning process at in 2013. With the involvement of 19 top managers and over 200 other employees, 23 scenario sessions were held, affecting 21 three-year business plans. The heads of three business areas chose to deploy scenario planning upfront, as an "inspiration" to their regular planning process, while the others deployed these sessions $e x$ post, as a way of "resilience testing". Hirschman reported the scenario planning sessions helped the managers collectively identify 136 "Act issues" and 80 "Prepare issues," which subsequently resulted in adjustments to the "Must-Win Battles" and "How to Win" sections of the 21 business plans.

\section{Confidence}

With no formal qualifications or domain expertise to engage Electroworks' engineers at risk assessment workshops and at resource allocation meetings, Lewis and his team acted as a facilitator. But they did their homework in response to the board's request for an ERM process - they spent four months "reading everything we could about it: publications by the Conference Board of Canada, by Tillinghast Towers Perrin, the Australian Standard $4360^{11}$, articles and many books." In the end, Lewis concluded "to do it [his] own way":

There has been a lot of bad literature, a lot of bad consultants; a lot of people were going down the wrong road. [ERM consultants] would charge us [a fortune] to do something they probably did the week before for some other company. In the end, I concluded ERM can be so simple and so logical - was it not for the many people who seek to complicate it.

Lewis' espoused practice of ERM required three people ("three personality types"):

The first one is someone to make it happen. That's me. Okay, somebody who will push down doors, is driven, and has the credibility and authority to open doors and make it happen. The second is a nice charismatic personality who people enjoy working with. And that was [the Workshop Facilitator] - an absolute charmer. A super nice guy, goodlooking, charming, very knowledgeable, who became a very good [workshop] facilitator. The third one is a person with an analytical mind who can manage the vast quantities of data [collected at the workshops]. You don't find those characteristics in the same person - so I teamed them together.

He consciously departed from conventional wisdom by deciding to "just start running workshops":

\footnotetext{
${ }^{11}$ Standards Australia (2004)
} 
The theory says go on, train and educate people on ERM by going and giving presentations. My answer to this was "No, no, no, you have to run workshops; that's the way you get others involved, engaged, and that's how they learn, not by sitting through a Power Point.

By 2003, ERM at Electroworks was sufficiently established so that Lewis could judge it as a success and confidently entered the wider ERM discourse by publishing articles and book chapters on Electroworks' ERM practice. Publcizing his approach to ERM was part of his campaign against "people who seek to complicate" ERM, but it also reassured the company's management team and board of directors that "we were ahead of the game and our regulator was so impressed with [our ERM] that they are going to take and mandate it for everyone else to do it this way [in the industry].

Having examined several software packages and attended consultants' presentations on risk databases, Hirschman concluded that "finding the right one [for Magic Toys] was rather difficult". He ended up developing his own Excel spreadsheet ("I've used Excel since 1984, I know how to do it"), which was maintained and updated by one of his team members, based on written or spoken input from "risk owners".

Hirschman continuously wheedled and cajoled business managers to send updates on risks and actions. He never used fiat and never referenced the ERM policy documents - he appeared permissive, and lenient but at the same time, the downside consequences of not responding was implicit in these communications. He described one instance when a late response cost a manager holiday time to catch up with his risk reporting:

I told him [the risk owner]: 'I need to know what you're doing'. He said, 'sure, how do we do this most easily?' I say, 'most easily, I've sent you the risk and I've sent you the template I'm using for updating mitigations. Who is doing what and why do we think it works? It's a questionnaire.' And he said, 'Okay. When do you need it by?' I say,

'Well, I can get the report out two or three days after you're done, so you decide.' The day before Christmas, he said, 'I didn't get to do it yet. Is it okay if I do it after Christmas?' I said, 'Sure, but we have to send the report to the board by $x x x$, and that would be demonstrating that you are not in control of something we think you are controlling so...' After Christmas, he admitted that he spent three hours filling in templates in his holiday, to give me that feedback by January, so we can have it in the updated report.

Hirschman made it clear to everyone that his responsibility concerned the design and facilitation of the SRM process - not more, not less. He pushed back on a request for quarterly risk reports from a board member arguing that "ours is a seasonal business - we have half the turnover the last ten weeks of Christmas; the majority of the rest around Easter. It doesn't make sense to make a first and third quarter report." When the board member insisted on the quarterly reporting, Hirschman stood his ground and persuaded the CEO that it would be "a waste of time". The director yielded.

Having facilitated the preparation of the bi-annual risk report, the risk team did not remain entirely silent. In the report, there was a separate section devoted to "what the Strategic Risk Management Office believes." Here Hirschman could be explicit and challenging:

"In the latest report I just sent out in June, I put in the comments that this year may be the first one since 2005 that we will not meet our targets. I had the CFO on the phone as soon as he saw the draft, telling me: 'Our target is $11 \%$ sales growth. That number is not in jeopardy.' And I said, 'Sorry, John, I don't agree. It is in jeopardy. I didn't 
say we won't make our targets. I said we may not make our targets. In fact I think it's in serious, severe jeopardy. We are growing - but year to date, we had an $8 \%$ growth on consumer sales, and you want to make it $11 \%$ by high season? That's not a done deal. By no way.' He still disagreed with me, but allowed me to send it to the board. Next, I had the VP Marketing on the phone. I had to explain that I ran my Monte Carlo simulation on our budgeted and "year to date" figures and what that means to them: "Guys, you are getting late for the party, but yet you are still cruising at 40 mph on the highway - why not take more risks, speed up to the 70 you are allowed to drive, if that will more likely take you to the party in time."

Over the years, Hirschman formulated a view of risk management that put emphasis on its enabling, rather than constraining aspect, and he put it in writing in a series of papers and book chapters coauthored by a business-school academic. Contradicting the corporate governance advocates and guidelines that considered risk management as a "line of defense" in the internal control landscape, Hirschman emphasized that the role of the risk management function was to support, rather than control managers:

I think one of the places where the traditional risk managers in other companies have problems is that they emerged - they come from a control environment, internal audit or something like that. That means that when they walk in the door, you see them as internal audit coming and checking you up. We do not come from that part of the business. We've never been into that - actually until a couple of years ago, we never had an internal audit function. But, we're coming with a license to ask questions that help them succeed. Because, well - SRM may be a part of controlling, but it's actually a part of supporting.

\section{Humility and frugality}

While the risk team remained small, as per Lewis' original vision (one person providing authority; a Workshop Facilitator and a Data Manager), its reach impacted much of the organization though workshops, the annual planning and the bi-annual updates. Lewis and team were quick to acknowledge that despite their perceived successes, their full vision for ERM was never accomplished, and perhaps will never be. Lewis summarized his "theoretical dream" as the "risk dashboard" - a software-enabled, computerized version of his risk reports, accessible anytime by any senior manager, providing up-to-date and fast graphic displays of all risk information, summarized into colourful risk maps and Top 10 risk lists, with drill-down capability into individual items. But Lewis was conscious that Electroworks did not have the "systems", skill set or "culture" to implement such a model.

Upon Lewis' retirement in 2012, Electroworks did not recruit a new CRO - the previous Workshop Facilitator (Larry White ${ }^{12}$ ) became Director of Enterprise Risk Management (and no longer reported directly to the CEO, but to the Treasurer). Unlike many ERM advocates, White did not perceive this seeming demotion of the risk function as a weakness:

Lots of consultants, lots of people speak at conferences about the importance of a top-down-driven risk function, supported by the CEO - I think that's actually a vulnerability. You cannot do ERM by fiat, I do not need the CEO to say to our guys "Every six months you must do a risk workshop with [White] and I want to see the report". But a good way for the CEO to support ERM is in the way she asks questions. Ours would say [to the business manager]: "OK, I've got your plan. How could this go wrong? What are your risks? You're not sure? Well, you know, there is this guy over here - Larry White - who can help you figure out. Why don't you go and see him, because he'll help you figure that out? Then you can come back to me and we can make this decision." So Risk Management gets

\footnotetext{
12 Pseudonym
} 
pulled into the business because there is a vacuum to fill, as opposed to me imposing myself, or somebody on my behalf imposing me, on them.

At Electroworks, the risk function's span of control (in terms of resources, decision rights and formal authority) remained narrow, and even narrowed over time. However, the willingness of the CEO and the business lines to participate in risk talk, made up for that frugality. Bringing about that wide span of support via the proliferation of an unobtrusive, business-relevant risk process and vocabulary, was the risk team's key achievement.

At Magic Toys, Hirschman faced a number of debacles as he built his own risk-management tools and processes. He noted that "the first couple of databases didn't work, the third one did." This trial-and-error approach characterized the development of the scenario process too. After the initial disappointment, Hirschman was ready to admit to senior managers that the exercise failed due to the lack of any "followthrough or action." Despite this acknowledgement, one of the senior managers expressed support and that became the catalyst for the further development of the tool:

In early 2011, I got to talk by coincidence with [senior manager] over a cup of coffee, and we got to talk about these scenarios and he said, 'You really have something good about this scenario discussion, quite great. Why didn't work?' I said, 'I really don't know. I understood it didn't work and I accept that it didn't work, but I really don't know why.' He said, 'Try to figure it out. See if we can make it work.' And I went back with that and said to myself over and over, 'okay, why didn't it work?', and contemplated why it didn't work and eventually, I found out where the flaws was: the ownership of the scenarios.

Hirschman and his team insisted that in the risk discussions, whatever tool was used to channel them, managers had to "keep their thunder". Hirschman explained :

Managers hate to be told what to do ... and the higher the organizational level, the more the resentment-so by letting them run the show, and by limiting scenario planning to a half-day workshop for each team, we got the proverbial foot in the door.

The risk team also made it clear that their role was merely facilitating, not advising. Lynne Matte, who was a former project manager, had to actively fight a natural enough inclination to become more directive: "As a risk manager, you should never take over [the discussion]. Even if you know the solution, keep your mouth shut." Hirschman added: "It's their decision, it's their perception, it's their risk. If I started to advise or correct them, I would start owning the stuff, and I can't do that."

Hirschman saw risk management as "commons sense", and highlighted the importance of "understanding the business and the industry". He was careful not to take any credit for the successes of the business. Commenting on Magic Toys eventual success at exceeding its 2013 sales targets, he concluded:

There is a benefit to knowing whether you are taking the right amount of risk. You need to be able to take chances, but you need to know how many chances you can take. We grew 25\% last year. I can't take the credit for that, but I pushed the ball. I told every manager who was willing to listen that we found that we were not taking enough risk. In the end, we were able to shift product sales and suddenly we were the winners because we had the products and we got more shelf space. We more than doubled our shelf space at Walmart. And with 200 million 
people through the stores every week, that matters. I am not part of Corporate Management [top management], and I cannot take credit for any of this. Risk management is a very, very small part of the success we've had.

Despite its humble rhetoric of simplicity, common sense, Hirschman created a risk function that had the ears of the board and senior management. This remained the case even when a management reorganization left the $\mathrm{CRO}$ with a reporting line to the Treasurer (who then reported to the CFO). Though formally the CRO was " 4 steps removed" from the board of directors, by 2013 he established a process that shaped the discussion of every business plan, and the biannual board meetings.

Hirschman commented that despite his seemingly frugal resources (and small team of two) he enjoyed a wide span of support.

I get all the support and all the time I need. If I want to go on training or to a conference, I get the funding. I have all the resources I need. I have the right to focus on strategic risks only. I don't do insurance. I don't do vendor risk management or anything like that. Other people are doing that.

Hirschman also built an invaluable relationship with the fourth-generation owner of the family-held firm, who had just got appointed to the Magic Toys board:

I benefit from the fact that I know the guy since he wore diapers, literally. He's a young guy, he's 32, he is just coming in and he wants to be a good owner and a good part of the board of directors. And he sees the risk management approach as the best way he can add value to the board of directors because none of the others really want to bother discussing this. It gives him a point of entry to say: OK, what about this? What about that? And add positively to the discussion

By mentoring the young owner, Hirschman's role acquired another layer of significance. He was becoming influential in the manner of the famous Grey Eminences of a by-gone era - operating "behind the scenes" in an unofficial capacity of their own making.

\section{Discussion and Conclusion}

This paper tracked the evolution of the role of two chief risk officers (CROs), and the tools and processes they have implemented in their respective organizations. While the companies are from very different industries (one is a power company, the other is a toy manufacturer), they both embraced the concepts and tools of Enterprise Risk Management. Over a number of years, at both firms, risk management transformed from a collection of "off-the-shelf", acquired tools and practices into a seemingly inevitable and tailored control process. The paper investigated the role of the CRO in making these transformations happen.

The $\mathrm{CRO}$ at Electroworks, by the facilitation of continuous risk talk in workshops and face-to-face meetings, over ten years, has succeeded in orchestrating the creation and proliferation of a new language (that of risk management), and established processes that regularly brought business people together from diverse places and hierarchical levels, to discuss issues of concern. Far from being self-evident, risk talk, manifest in, for example, 1-5 assessments of "impact and likelihood of risk", and formally documented in risk maps and "lists of top 10 risks", took a long time to proliferate. The contribution of the CRO (and his small team) was to co-opt the business in the creation and use of risk talk. By merely providing a few rudimentary concepts and a minimal risk vocabulary, the $\mathrm{CRO}$ was able to get business people to fill in troubling gaps in meaning, and to add the rules of use, by for example delegating the definition of "1-5 impact scales" to those able to make sense, and also to make use, of them. The final test 
of the acceptance of risk talk was its formal linking to resource allocation in the annual budgeting process, which gave risk management permanence, significance and a sense of inevitability.

The second case, in a seeming contrast, focused on a CRO, who initially tried and failed to create linkages of permanence and significance between some conventional ERM tools (similar to those championed by his counterpart above) and the business lines. After a period of search, the CRO settled on a less conventional risk-identification tool, scenario planning, and facilitated its transformation, over five years from an ad hoc future-gauging exercise to widely accepted risk talk - and a seemingly selfevident element of the annual business planning process.

The two cases highlight that the role of the CRO may be less about the packaging and marketing of risk management tools to business managers, but instead, the facilitation of the creation and internalization of a specific type of risk talk as a legitimate, cross-functional language of business. The risk-management function may be most successful when it resists conventional and conflicting demands to be either close to, or independent from, business managers. Instead, by acting as a facilitator of risk talk the CRO can enable the real work of risk management to take place not in his own function, but in the business lines. In both cases, facilitation involved a significant degree of humility on the part of the CRO, manifest in limited (and paradoxically decreasing) formal authority and meagre resources. Their skill was to build an informal network of relationships with executives and business managers, which allowed them to resist being stereotyped as either compliance champions or business partners. Instead they created and shaped the perception of their role which was of their own making: a careful balancing act between keeping one's distance and staying involved.

This analysis suggests that calls for increasing investments in risk management, and for the formal inclusion of senior risk officers in the C-suite might be misguided. In order to close the expectations gap, risk managers need first and foremost commitment from others in the organization to accept a relevant and situationally contingent version of risk management, tailored to their needs. Thus the sign of success of the humble CRO is not so much in her ability to go "beyond the compliance role" or turn into a "business partner", but in her ability to bring about consequential risk talk where it matters, in the business lines, helping those who carry out the real work of risk management - managing risks. 


\section{References}

Accenture. Accenture 2013 Global Risk Management Study: Risk Management for an Era of Greater Uncertainty, 2013.

Committee of Sponsoring Organizations of the Treadway Commission (COSO). Enterprise risk management framework. New York, NY: American Institute of Certified Public Accountants, 2004.

Deloitte. Global Risk Management Survey, Eighth Edition: Setting a Higher Bar, 2013.

Economist Intelligence Unit Limited, Risk Management in the Front Line, 2010.

International Standards Organisation (ISO). ISO 31000:2009, Risk Management-Principles and Guidelines. Geneva: International Standards Organisation, 2009.

KPMG. Risk Management: A Driver of Enterprise Value in the Emerging Environment, 2011

KPMG. Expectations of Risk Management Outpacing Capabilities - It's Time For Action, May 2013.

Power, M.K. Organized Uncertainty - Designing a World of Risk Management. Oxford: Oxford University Press, 2007.

RIMS and Advisen Ltd. 2013 RIMS Enterprise Risk Management (ERM) Survey, August 2013.

Simons, R. Levers of Organization Design. Boston, MA: Harvard Business School Press, 2005.

Standards Australia. AS/NZS 4360:2004 Risk management (3 ${ }^{\text {rd }}$ edition). Sydney, Australia: Standards Australia Publications, 2004. 


\section{Appendix 1 - Electroworks Interviews}

\begin{tabular}{|c|c|c|}
\hline $\begin{array}{c}\text { Interview } \\
\text { Date }\end{array}$ & \begin{tabular}{l}
\multicolumn{1}{c}{ Initials of } \\
interviewee \\
nature of meeting \\
attended \\
\end{tabular} & Title(s) \\
\hline $5 / 7 / 2008$ & B.S. & Chief Financial Officer \\
\hline $5 / 7 / 2008$ & J.F. & Senior Vice President, Internal Audit and Chief Risk Officer \\
\hline $5 / 7 / 2008$ & R.Q. & Director, Enterprise Risk Management \\
\hline $5 / 8 / 2008$ & G.R. & Director, Customer Strategy \& Conservation Officer \\
\hline $5 / 8 / 2008$ & G.V.D. & Director, Asset Management \\
\hline $5 / 8 / 2008$ & J.T. & Director, Integrated Strategy \\
\hline $5 / 8 / 2008$ & L.F. & Chief Executive Officer \\
\hline $5 / 8 / 2008$ & P.G. & Director, Public Relations \\
\hline $5 / 9 / 2008$ & J.F. & Senior Vice President, Internal Audit and Chief Risk Officer \\
\hline $5 / 9 / 2008$ & S.F. & Chief Regulatory Officer \\
\hline $7 / 10 / 2008$ & J.F. & Senior Vice President, Internal Audit and Chief Risk Officer \\
\hline $6 / 1 / 2009$ & G.V.D. & Director, Asset Management \\
\hline $6 / 1 / 2009$ & G.S. & Engineer \\
\hline $6 / 1 / 2009$ & J.F. & Senior Vice President, Internal Audit and Chief Risk Officer \\
\hline $6 / 1 / 2009$ & L.F. & Chief Executive Officer \\
\hline $6 / 3 / 2009$ & C.M. & Executive Vice President, Strategy and Planning \\
\hline $6 / 3 / 2009$ & M.D. & Senior Vice President, Customer Operations \\
\hline $6 / 3 / 2009$ & S.F. & Chief Financial Officer \\
\hline $11 / 1 / 2011$ & J.F. \& R.Q. & $\begin{array}{l}\text { Senior Vice President, Internal Audit and Chief Risk Officer \& } \\
\text { Director, Enterprise Risk Management }\end{array}$ \\
\hline $11 / 1 / 2011$ & M.D. & Senior Vice President, Customer Operations \\
\hline $11 / 1 / 2011$ & R.S. & Vice President, Customer Services \\
\hline $11 / 2 / 2011$ & J.F. \& R.Q. & $\begin{array}{l}\text { Senior Vice President, Internal Audit and Chief Risk Officer \& } \\
\text { Director, Enterprise Risk Management }\end{array}$ \\
\hline $11 / 2 / 2011$ & N.L. \& R.W. & Manager, Account Management and GIS Program Manager \\
\hline $7 / 16 / 2013$ & R.Q. & Director, Enterprise Risk Management \\
\hline $12 / 10 / 2013$ & R.Q. & Director, Enterprise Risk Management \\
\hline
\end{tabular}

\section{Appendix 2 - Magic Toys Interviews}

\begin{tabular}{|l|l|l|}
\hline $5 / 2 / 2012$ & H.L. & Senior Director, Risk Management \\
\hline $5 / 2 / 2012$ & J.H. \& T.P. & $\begin{array}{l}\text { Senior Vice President, Global Quality and Engineering \& Customer } \\
\text { Service Advisor }\end{array}$ \\
\hline $5 / 2 / 2012$ & J.K. & Senior Director, Operating Model Leverage \\
\hline $5 / 2 / 2012$ & M.N. & Chief Marketing Officer \\
\hline
\end{tabular}




\begin{tabular}{|c|c|c|}
\hline $5 / 2 / 2012$ & R.S. & Senior Vice President, Corporate Affairs \\
\hline $5 / 2 / 2012$ & $\begin{array}{l}\text { H.L., A.M.B, \& } \\
\text { L.M. }\end{array}$ & $\begin{array}{l}\text { Senior Director, Risk Management; Director, Strategic Risk } \\
\text { Management; \& Senior Director, Consumer Goods }\end{array}$ \\
\hline $5 / 3 / 2012$ & H.L. & Senior Director, Risk Management \\
\hline $5 / 3 / 2012$ & J.P.P. & Senior Vice President, Market Group Asia \& Emerging Markets \\
\hline $5 / 3 / 2012$ & J.V. & Vice President, Digital Business \\
\hline $5 / 3 / 2012$ & L.T.B. \& V.M.H. & Vice Presidents, Group Treasury \\
\hline $5 / 3 / 2012$ & T.N. \& C.B. & $\begin{array}{l}\text { Director, Digital Program Management, Office, and Quality \& } \\
\text { Manager, Outbound Licensing }\end{array}$ \\
\hline $6 / 25 / 2012$ & $\begin{array}{l}\text { Scenario Planning } \\
\text { Session }\end{array}$ & \\
\hline $6 / 25 / 2012$ & O.T. & Country Manager, Asia and Emerging Markets \\
\hline $6 / 25 / 2012$ & U.C. & Vice President, Asia and Emerging Markets \\
\hline $6 / 26 / 2012$ & A.M.B. \& R.F. & $\begin{array}{l}\text { Director, Strategic Risk Management \& Senior Strategic Risk } \\
\text { Manager }\end{array}$ \\
\hline $6 / 26 / 2012$ & K.F.C. \& A.J.M. & Senior Manager, Finance \& Manager, Market Logistics \\
\hline $6 / 26 / 2012$ & R.F. & Senior Strategic Risk Manager \\
\hline $6 / 26 / 2012$ & $\begin{array}{l}\text { R.F. \& H.L. } \\
\text { (Morning) }\end{array}$ & Senior Strategic Risk Manager \& Senior Director, Risk Management \\
\hline $6 / 26 / 2012$ & $\begin{array}{l}\text { R.F. \& H.L. } \\
\text { (Afternoon) }\end{array}$ & Senior Strategic Risk Manager \& Senior Director, Risk Management \\
\hline $6 / 26 / 2012$ & $\begin{array}{l}\text { R.F. \& H.L. } \\
\text { (Feedback) }\end{array}$ & Senior Strategic Risk Manager \& Senior Director, Risk Management \\
\hline $6 / 27 / 2012$ & D.H. & Director, External Relations \\
\hline $9 / 13 / 2012$ & J.K. & Senior Director, Operating Model Development \\
\hline 9/13/2012 & K.F.C. \& R.F. & $\begin{array}{l}\text { Head of Emerging Markets Operations \& Senior Strategic Risk } \\
\text { Manager }\end{array}$ \\
\hline 9/13/2012 & O.T. & Country Manager, Asia and Emerging Markets \\
\hline $9 / 13 / 2012$ & R.F. & Senior Strategic Risk Manager \\
\hline $9 / 14 / 2012$ & A.J.M. & Manager, Market Logistics \\
\hline $9 / 14 / 2012$ & D.H. & Director, External Relations \\
\hline 9/14/2012 & K.F.C. & Head of Emerging Markets Operations \\
\hline $9 / 14 / 2012$ & R.F. & Senior Strategic Risk Manager \\
\hline 9/14/2012 & U.C. & Vice President, Asia and Emerging Markets \\
\hline $11 / 20 / 2012$ & H.L. & Senior Director, Risk Management \\
\hline $11 / 20 / 2012$ & K.F.C. & Head of Emerging Markets Operations \\
\hline $11 / 20 / 2012$ & O.A. & Senior Key Account Manager \\
\hline 9/17/2013 & H.L. & Senior Director, Risk Management \\
\hline 9/17/2013 & U.C. & Vice President, Asia and Emerging Markets \\
\hline $9 / 18 / 2013$ & A.J.M. & Manager, Market Logistics \\
\hline
\end{tabular}




\begin{tabular}{|l|l|l|}
\hline $9 / 18 / 2013$ & H.L. & Senior Director, Risk Management \\
\hline $9 / 18 / 2013$ & Team meeting & Risk team \\
\hline $9 / 18 / 2013$ & J.K. & Senior Director, Operating Model Development \\
\hline $9 / 18 / 2013$ & K.C. & Head of Emerging Markets Operations \\
\hline $9 / 18 / 2013$ & O.T. and K.C. & $\begin{array}{l}\text { Country Manager, Asia and Emerging Markets; Head of Emerging } \\
\text { Markets Operations }\end{array}$ \\
\hline $9 / 18 / 2013$ & O.T. & Country Manager, Asia and Emerging Markets \\
\hline $11 / 15 / 2013$ & J.K. & Senior Director, Operating Model Development \\
\hline $11 / 18 / 2013$ & S.K. & Senior Vice President, Shopper Marketing \& Channel Development \\
\hline $12 / 4 / 2013$ & H.L. & Senior Director, Risk Management \\
\hline
\end{tabular}


Appendix 3 Electroworks: Objectives-Impact Matrix

\begin{tabular}{|c|c|c|c|c|c|c|c|}
\hline Objective & Attribute & Event & $\begin{array}{c}5 \\
\text { Worst Case } \\
\end{array}$ & $\begin{array}{c}4 \\
\text { Severe } \\
\end{array}$ & $\begin{array}{c}3 \\
\text { Major }\end{array}$ & $\begin{array}{c}2 \\
\text { Moderate }\end{array}$ & $\begin{array}{l}1 \\
\text { Minor }\end{array}$ \\
\hline \multirow{3}{*}{ FINANCIAL } & Net Income & $\begin{array}{l}\text { Net Income Shortfall } \\
\text { (after tax, in one year) }\end{array}$ & $>\$ 150 \mathrm{M}$ & $\$ 75 \mathrm{M}-\$ 150 \mathrm{M}$ & $\$ 25 \mathrm{M}-\$ 75 \mathrm{M}$ & $\$ 5 M-\$ 25 M$ & $<\$ 5 \mathrm{M}$ \\
\hline & Credit Worthiness & $\begin{array}{l}\text { Change in financial ratios or } \\
\text { risk }\end{array}$ & $\begin{array}{l}\text { Event of default; } \\
\text { Unable to raise any capital due } \\
\text { to credit rating. }\end{array}$ & $\begin{array}{l}\text { Credit rating downgrade to } \\
\text { below investment grade; } \\
\text { Unable to raise full amount } \\
\text { required capital. }\end{array}$ & Credit rating downgrade. & $\begin{array}{l}\text { Hydro One Inc. put on credit } \\
\text { "watch". }\end{array}$ & $\begin{array}{l}\text { Credit rating agencies and } \\
\text { bondholders express concern. }\end{array}$ \\
\hline & Value of the Enterprise & Loss in Value of Hydro One & Loss of $>25 \%$ Value & Loss of $10-25 \%$ Value & Loss of 5-10\% Value & Loss of $1-5 \%$ Value & Loss of $<1 \%$ Value \\
\hline \multirow{3}{*}{ REPUTATION } & Public Profile & $\begin{array}{l}\text { Negative media attention; } \\
\text { Opinion leader and public } \\
\text { Criticism }\end{array}$ & $\begin{array}{l}\text { National media attention; } \\
\text { Opinion leaders/customers } \\
\text { nearly unanimous in public } \\
\text { criticism. }\end{array}$ & $\begin{array}{l}\text { Provincial media attention; } \\
\text { Most opinion leaders/ } \\
\text { customers publicly critical. }\end{array}$ & $\begin{array}{l}\text { Significant local attention; } \\
\text { Several opinion leaders/ } \\
\text { customers publicly critical. }\end{array}$ & $\begin{array}{l}\text { Letter(s) to Minister } \\
\text { of Energy. }\end{array}$ & $\begin{array}{l}\text { Letter(s) to Senior } \\
\text { Management. }\end{array}$ \\
\hline & Shareholder confidence & $\begin{array}{l}\text { Owner/ shareholder } \\
\text { involvement in Hydro One } \\
\text { operations }\end{array}$ & $\begin{array}{l}\text { Complete loss of confidence; } \\
\text { CEO and Board replaced by } \\
\text { the owner. }\end{array}$ & $\begin{array}{l}\text { Extensive loss of confidence; } \\
\text { CEO or several Sr. Managers } \\
\text { replaced. }\end{array}$ & $\begin{array}{l}\text { Credit Rating agencies and } \\
\text { bondholders express concern. }\end{array}$ & $\begin{array}{l}\text { Confidence in question; owner } \\
\text { requests significant changes to } \\
\text { business plan. }\end{array}$ & $\begin{array}{l}\text { Some concern with } \\
\text { management decisions; } \\
\text { occasional requests from } \\
\text { owner for details. }\end{array}$ \\
\hline & Employee confidence & Employee Dissatisfaction & $\begin{array}{l}\text { Widespread departures of key } \\
\text { staff with scarce skills or } \\
\text { knowledge. }\end{array}$ & $\begin{array}{l}\text { Sharp, sustained drop in } \\
\text { employee survey results; } \\
\text { departures of key staff with } \\
\text { scarce skills or knowledge. }\end{array}$ & $\begin{array}{l}\text { Sharp decline in employee } \\
\text { survey results; sharp increase } \\
\text { in grievances. }\end{array}$ & $\begin{array}{l}\text { Modest decline in employee } \\
\text { survey results; modest } \\
\text { increase in grievances. }\end{array}$ & $\begin{array}{l}\text { Less than planned } \\
\text { improvements in employee } \\
\text { survey results. }\end{array}$ \\
\hline $\begin{array}{l}\text { REGULATORY } \\
\text { RELATIONSHIP }\end{array}$ & Meet License Conditions & $\begin{array}{l}\text { Loss of Credibility with } \\
\text { Regulators }\end{array}$ & $\begin{array}{l}\text { General loss of Credibility; } \\
\text { Intrusive Involvement. }\end{array}$ & $\begin{array}{l}\text { Some loss of Credibility; } \\
\text { Excessive Involvement. }\end{array}$ & $\begin{array}{l}\text { Some Concerns re: } \\
\text { Competence; Difficult } \\
\text { Demands. }\end{array}$ & $\begin{array}{l}\text { Increase in Reporting Detail } \\
\text { and Frequency. }\end{array}$ & Balanced; some challenges. \\
\hline \multirow{3}{*}{$\begin{array}{l}\text { CUSTOMERI } \\
\text { RELIABILITY }\end{array}$} & OEB Service Quality Indices & $\begin{array}{l}\text { Failure to Meet Service Quality } \\
\text { Indices }\end{array}$ & $\begin{array}{l}\text { Achieve } 25 \% \text { of Overall } \\
\text { Expected Performance. }\end{array}$ & $\begin{array}{l}\text { Achieve } 67 \% \text { of Overall } \\
\text { Expected Performance. }\end{array}$ & $\begin{array}{l}\text { Achieve } 80 \% \text { of Overall } \\
\text { Expected Performance. }\end{array}$ & $\begin{array}{l}\text { Achieve } 90 \% \text { of Overall } \\
\text { Expected Performance. }\end{array}$ & $\begin{array}{l}\text { Achieve } 95 \% \text { of Overall } \\
\text { Expected Performance. }\end{array}$ \\
\hline & $\begin{array}{l}\text { Direct Customers, Local } \\
\text { Distribution Companies, } \\
\text { Generators }\end{array}$ & $\begin{array}{l}\text { Increase in customer } \\
\text { dissatisfaction with Hydro One }\end{array}$ & $\begin{array}{l}\text { Numerous Direct Customers } \\
\text { initiate action such as bypass } \\
\text { or relocation; Numerous LDC's } \\
\text { default on bill payments; } \\
\text { Generator reluctance to locate } \\
\text { in Ontario leads to shortages. }\end{array}$ & $\begin{array}{l}\text { Exponential increase in } \\
\text { customer lawsuits for direct } \\
\text { and/or collateral damage } \\
\text { believed to be caused by } \\
\text { Hydro One; Complaints to } \\
\text { provincial government } \\
\text { increase dramatically. }\end{array}$ & $\begin{array}{l}\text { Customer associations step up } \\
\text { lobbying efforts for stricter } \\
\text { penalties against Hydro One. }\end{array}$ & $\begin{array}{l}\text { One "large" customer } \\
\text { experiences significant } \\
\text { production losses due to } \\
\text { Hydro One actionslinaction; } \\
\text { high level (CEO, COO, etc.) } \\
\text { calls to Hydro One CEO's } \\
\text { office. }\end{array}$ & $\begin{array}{l}\text { Increase in number of } \\
\text { customer complaints. }\end{array}$ \\
\hline & $\begin{array}{l}\text { Residential and Small } \\
\text { Business Customers }\end{array}$ & $\begin{array}{l}\text { Increase in customer } \\
\text { dissatisfaction with Hydro One } \\
\text { service quality }\end{array}$ & $\begin{array}{l}\text { Significant numbers of } \\
\text { customers begin to default on } \\
\text { bill payments. }\end{array}$ & $\begin{array}{l}\text { Exponential (>50\%) increase } \\
\text { in call centre volumes and } \\
\text { complaints received by field } \\
\text { staff. }\end{array}$ & $\begin{array}{l}\text { Call centre volumes increase } \\
\text { noticeably ( } 25 \% \text { ) } \text { notitieable } \\
\text { increase in complaints } \\
\text { received by field staff. }\end{array}$ & $\begin{array}{l}\text { Sharp deterioration in } \\
\text { customer satisfaction as per } \\
\text { survey responses. }\end{array}$ & $\begin{array}{l}\text { Moderate deterioration in } \\
\text { customer satisfaction as per } \\
\text { survey responses. }\end{array}$ \\
\hline \multirow{2}{*}{ COMPETITIVENESS } & Unit Cost Reduction & $\begin{array}{l}\text { Failure to Reduce Unit Costs } \\
\text { (incl. overhead \& non-billable } \\
\text { time) }\end{array}$ & Unit Costs increase by $>25 \%$ & $\begin{array}{l}\text { Unit Costs increase by } 15 \%- \\
25 \%\end{array}$ & $\begin{array}{l}\text { Unit Costs increase by } 10 \% \text { - } \\
15 \%\end{array}$ & $\begin{array}{l}\text { Unit Costs increase by } 5 \% \\
10 \%\end{array}$ & Unit costs not reduced \\
\hline & $\begin{array}{l}\text { Work Program } \\
\text { Accomplishment }\end{array}$ & Work Program Shortfall & $\begin{array}{l}>10 \text { Critical Projects late or; } \\
<50 \% \text { of noncritical work } \\
\text { completed. }\end{array}$ & $\begin{array}{l}\text { 5-10 Critical Projects late or } \\
50 \%-70 \% \text { of noncritical work } \\
\text { completed. }\end{array}$ & $\begin{array}{l}3-5 \text { Critical Projects late or } \\
70 \%-85 \% \text { of non critical work } \\
\text { completed. }\end{array}$ & $\begin{array}{l}\text { 1-3 Critical Projects late or } \\
>85 \% \text { of non critical work } \\
\text { completed. }\end{array}$ & $\begin{array}{l}\text { No Critical Projects late } \\
>85 \% \text { of non critical work } \\
\text { completed. }\end{array}$ \\
\hline \multirow[t]{2}{*}{$\begin{array}{l}\text { SAFETY AND } \\
\text { ENVIRONMENT }\end{array}$} & Environmental Performance & Adverse Environmental Impact & $\begin{array}{l}\text { Widespread offsite impacts } \\
\text { e.g., regional or municipal } \\
\text { water supply. }\end{array}$ & $\begin{array}{l}\text { Multiple local offsite impacts } \\
\text { e.g., multiple residential } \\
\text { properties or private water } \\
\text { supplies. }\end{array}$ & $\begin{array}{l}\text { Significant local offsite impact } \\
\text { e.g., a public thoroughfare; } \\
\text { Significant spill/release with } \\
\text { impact on Hydro One Inc. } \\
\text { property only }\end{array}$ & $\begin{array}{l}\text { Minor local offsite impact } \\
\text { e.g., a single residential } \\
\text { property or private water } \\
\text { supply). }\end{array}$ & $\begin{array}{l}\text { Minor impact on Hydro One } \\
\text { Inc. property only. }\end{array}$ \\
\hline & Public Safety & $\begin{array}{l}\text { Public Injuries with Hydro One } \\
\text { at fault. }\end{array}$ & $\begin{array}{l}\text { Fatality or major permanent } \\
\text { disability. }\end{array}$ & $\begin{array}{l}\text { Significant increase in number } \\
\text { of injuries. }\end{array}$ & $\begin{array}{l}\text { Moderate increase in number } \\
\text { of injuries. }\end{array}$ & $\begin{array}{l}\text { Small increase in number of } \\
\text { injuries. }\end{array}$ & No change. \\
\hline
\end{tabular}


